\title{
Trade Shows and SME Internationalisation: Networking for Performance
}

\author{
Stephan Gerschewski ${ }^{1}$. Natasha Evers ${ }^{2}$ - Anh Tuan Nguyen ${ }^{3,4}$. \\ Fabian Jintae Froese ${ }^{5}$
}

Received: 29 January 2019 / Revised: 29 January 2020 / Accepted: 8 February 2020 /

Published online: 15 July 2020

(c) The Author(s) 2020

\begin{abstract}
Trade shows are a key vehicle where SMEs often develop networks, through which valuable resources for internationalisation can be acquired. However, there tends to be a scarcity of research on the performance outcomes of network development of international SMEs (ISMEs), particularly, in trade show forums. Adopting a network-based view, we investigate the influence of trade shows on the performance of ISMEs. Results from a survey of 229 Australian and New Zealand SMEs indicate that proactiveness is positively associated with the development of networks through trade shows, which, in turn, increases the firms' operational performance, but not financial performance. In addition, the effect of trade shows is generally more beneficial for ISMEs in the service industry, compared to other industries.
\end{abstract}

Keywords Small and medium-sized enterprise (SME) · Network · Trade show · Internationalisation $\cdot$ Firm performance

\section{Introduction}

The study of small firm internationalisation has captured increased attention in the literature since the 1990s. This has been evident by the substantial growth of studies, accruing to a large body of knowledge regarding internationalisation processes of international, small and medium-sized enterprises (ISMEs) (Ryan

Fabian Jintae Froese

ffroese@uni-goettingen.de

1 University of Kent, Canterbury, UK

2 Trinity College Dublin, Dublin, Ireland

3 University of Goettingen, Göttingen, Germany

4 VNU University of Economics and Business, Hanoi, Vietnam

5 University of Goettingen, Göttingen, Germany 
et al. 2019). Due to a lack of resources and the small size of ISMEs, a key rationale is that the dynamics of their firms' internationalisation processes often differ considerably from large multinational enterprises (MNEs) (Cho and Lee 2018; Ojala et al. 2018). One such difference relates to their companies' higher dependency on and usage of their business and social networks for their firms' international development and growth (Jeong et al. 2017). Studies on the entrepreneurs' personal social and business networks in small firm internationalisation have recently become more numerous and popular, especially in academia (e.g., Crick and Spence 2005).

Prior research has indicated that the international growth and expansion of SMEs have relied on their dependency to leverage the needed foreign market knowledge and resources through their respective network relationships (e.g., Jeong et al. 2017; Ryan et al. 2019). Johanson and Vahlne (2009) expanded the orginal Uppsala model of internationalisation by including the role of business networks where the internationalising company is interdependent with and integrated in wider foreign business networks. Inter-organisational networks can support ISMEs to reduce the liabilities of foreignness (Hymer 1976). Without the firm's managerial proactiveness in mobilising their networks for resources, international growth and market expansion would be generally deemed problematic (Evers 2011; Karra et al. 2008).

Networks in the company's have an important function in the internationalisation process in the 'network model of internationalisation' (Johanson and Mattsson 1988). The model argues that SMEs tend to internationalise through business networks and operate in an industrial network setting with different actors being connected to each other. Industrial networks usually consist of social and business relationships across vertical and horizontal actors, including customers, and other stakeholders (Axelsson and Easton 1992; Ryan et al. 2019).

Despite the high frequency of network studies in understanding SME internationalisation, we know little about the role of networks in predicting the performance of ISMEs (Jin and Jung 2016; Zain and Ng 2006). Less is know about how networks are created for access into foreign markets (Johanson and Vahlne 2009; Measson and Campbell-Hunt 2015) and the actual forum and nodes where such networking development, connections and exchanges occur (Ryan et al. 2015). The personal and social nature of forming and building relationships indicate that spatial proximity is important to develop network relationships (Evers and Knight 2008). Trade shows are generally considered a key component of the marketing for SMEs (Rinallo et al. 2016), and trade fairs can act as temporary industry clusters in an intensified form by hosting industrial networks for a specified, limited time (Maskell et al. 2006).

Participating in trade shows is an important mechanism to acquire and develop business networks (Harris and Wheeler 2005; Measson and Campbell-Hunt 2015). Few studies have noted the importance of trade shows for small firm internationalisation providing a temporary, but critical industry node for networking, thus going beyond a firm's traditional selling and commercial activities (Ryan et al. 2015). In such network forums, knowledge, although limited, has indicated that trade shows allow actors to build and strengthen social networks to accelerate the internationalisation process (Evers and Knight 2008). However, the literature has generally 
scarcely addressed the potential performance outcomes of networking activities at trade shows (Tafesse and Skallerud 2017).

In this study, we build on these research gaps and investigate how trade shows may influence the performance of ISMEs. The network model of internationalisation (e.g., Johanson and Mattsson 1988, 1992) provides the conceptual basis to examine the impact of network development at trade shows on ISMEs' performance. We further leverage theoretical insights from Johanson and Vahlne's (2009) developed Uppsala perspective on business networks in firm internationalisation.

In addition, we draw on extant studies positing that access to vital resources for international performance is driven by network mobilisation brought about by proactiveness as one component of entrepreneurial orientation (Covin and Slevin 1989). We, thus, examine the impact of proactiveness on the network development of ISMEs at trade shows. To address these research objectives, we conduct a survey of 229 Australian and New Zealand ISMEs, operating in different industry sectors. Further, in response to recent calls in the literature regarding the notion of export and internationalisation readiness (Gerschewski 2017; Tan et al. 2007, 2018), we examine the post-internationalisation stage whereby we specifically investigate the firms' initial foreign market entry and internationalisation process, covering the initial first 5 years of firm internationalisation.

\section{Literature Review}

\subsection{Trade Shows and SME Internationalisation}

Trade shows are regular events, where a large number of companies are able to present and 'showcase' their main products and services (Kirchgeorg et al. 2010). Trade shows can provide opportunities for firms to increase their global reach and exposure, to advertise their products and services, and to establish new business relationships and enable efficient knowledge exchange with key stakeholders (Brown et al. 2017; Evers 2011; Evers and Knight 2008).

Trade shows are generally viewed favourably and positively by firms, which are already 'ready to export' (Wilkinson and Brouthers 2000). Axinn (1988) indicated that trade show attendance yields an increase in export sales, thus often resulting in unsolicited orders from new customers and clients. Wilkinson and Brouthers (2006) found that trade show attendance can lead to superior export performance.

\subsection{Conceptual Model}

The network view (Johanson and Mattsson 1988) provides the key theoretical basis for this study. The model argues that firms depend on assets and resources that other companies control, and acquire access to network resources via a specific position in the focal networks. The firm's knowledge acquisition is mainly dependent on the establishment of international networks and the inter-dependencies among the actors in the business, industrial, and social networks (e.g., 
Andersson et al. 2018; Axelsson and Easton 1992; Johanson and Mattsson 1988). The model states that company survival is generally dependent on establishing networks during the internationalisation process (Johanson and Vahlne 2003). A company enters foreign markets by developing networks in new international markets (Johanson and Mattsson 1988), e.g., establishing new relationships with stakeholders of the firm (e.g., customers, suppliers, etc.) (Johanson and Vahlne 2003). After attaining a foothold position in a network, the company moves to the penetration phase, where it develops relationships and increases resource commitments in markets. Thus, firms start learning and establish trust and commitment, which are key to succeed in international markets. The integration phase signals greater global reach and a higher degree of internationalisation, in terms of the competitive position in international markets (Chetty and Holm 2000).

Johanson and Vahlne (2009) indicate that networks between organisations are instrumental in influencing international market selection and foreign market entry mode, identifying two preconditions for firm internationalisation. The first is attaining 'insidership' within an established network which is pertinent to a firm's internationalisation process. Industrial markets are generally considered as networks of relationships, where companies tend to be linked to each other, thus rendering them 'insiders' in the relevant network(s) for successful internationalisation. If they remain unconnected to this network, there is a liability of outsidership. Liability of outsidership can occur when a firm's challenges in internationalisation are connected to relationship- and network-specificity and less to country-specificity. Thus, the firm does not necessarily know who the stakeholder are, and how they may be connected to each other. Second, these relationships are critical sources of acquiring learning where knowledge is accrued from these relationships about foreign markets. Such relationships are generally built upon trust and commitment. Thus, an extensive network of relevant business relationships equips firms with improved knowledge levels (Kogut 2000). We argue in our study that trade shows can serve as a key forum to facilitate the entry and development of the firms linking them to a relevant network of relationships comprising valuable business and social networks for superior firm performance. We also contend that entrepreneurial proactiveness, a component of entrepreneurial orientation (EO) (Covin and Slevin 1989), is an important antecedent for our understanding of how networks at trade shows are utilised by ISMEs for positively contributing to their firm performance. We argue that trade shows are particularly pertinent to the extension phase of internationalisation where network relationships with customers, distributors, agents, and suppliers are formed and developed as the company is entering a new foreign market. Thus, the notion of 'proactiveness' becomes important in that a proactive approach can facilitate the establishment and maintenance of network relationships with key industry stakeholders (e.g., suppliers, distributors, and buyers). Recent research by Brown et al. (2017) suggests that when the firm's top management focuses on trade show marketing it often leads to superior firm performance. Therefore, we hypothesise that the development of trade show networks mediates the relationship between firm proactiveness and company performance. Furthermore, we hypothesise that industry can serve as an important moderator between development of networks 
at trade shows and performance, in that network development tends to be more important in high contact industries such as services due to the intangible nature and the increased relevance of after-sales services in service industries as compared to manufacturing sectors.

Figure 1 presents our conceptual model. The hypotheses are developed more indepth in the following section.

\section{Hypotheses}

\subsection{Proactiveness and Network Development of International SMEs}

International performance of SMEs is strongly shaped by the managerial competence of the entrepreneur (Chandler and Hanks 1994). The concept of entrepreneurial orientation is a key research topic in the extant SME internationalisation literature (e.g., Evers 2011; Evers et al. 2019), and operationalised based on the components of (1) proactiveness, (2) innovativeness, and (3) risk-taking (Covin and Slevin 1989). The ability of managers to proactively network effectively has been identified as an essential capability, including foreign market knowledge and customer referrals for international market expansion (Evers et al. 2012; Weerwardena et al. 2007). It is well established that managers deploy relational social capital in their international networks for rapid foreign market entry and expansion (Ryan et al. 2019).

Earlier studies have noted that when international networks are proactively leveraged by SMEs, they bring about more effective implementation of strategies of SMEs, and can help develop their dynamic marketing capabilities for international performance (Evers et al. 2012). Proactiveness has been found to be a central

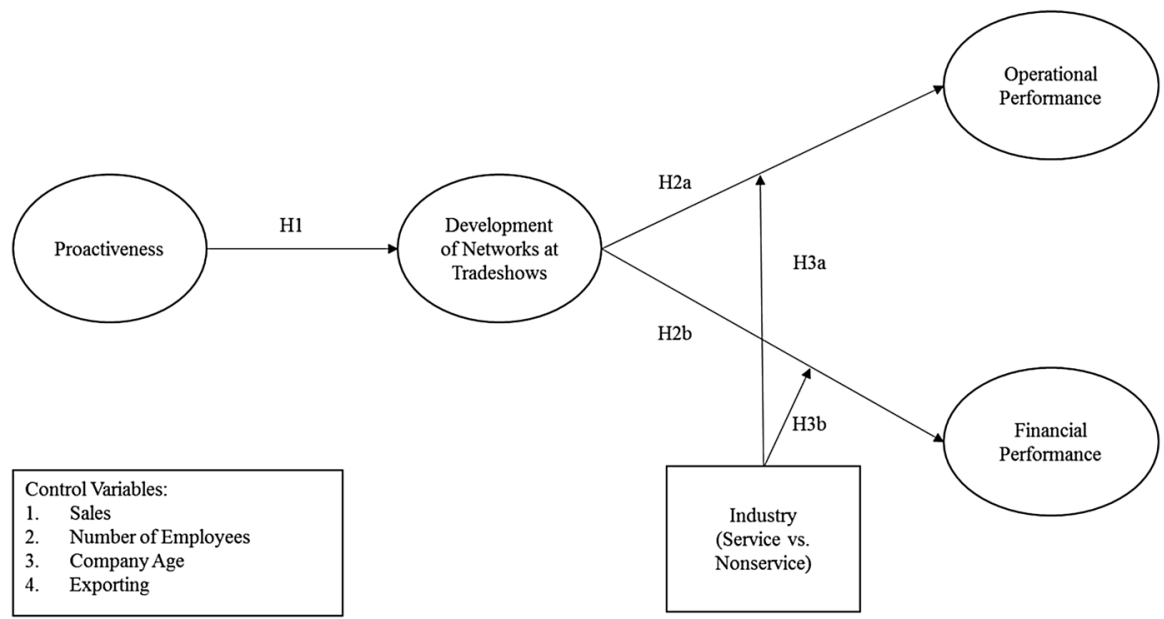

Fig. 1 Conceptual model 
component of entrepreneurial orientation, thus providing strong support to the entrepreneurial nature of ISMEs (Gerschewski et al. 2016).

We focus on 'proactiveness' in our study because prior related studies found relationships with the performance of SME exporters (Francis and Collins-Dodd 2000). The other two components of EO; innovativeness and risk-taking; tend to have less significant performance implications as compared to proactiveness. Proactiveness is also considered an important character trait of successful entrepreneurs, and it has been linked to perseverance and passion (Gerschewski et al. 2016).

International firm's proactiveness to leverage external networks will help obtain assets needed for international growth, e.g., knowledge, operational capabilities, and finance (Evers et al. 2012). As we focus on network building for resource acquisition and leveraging for the ISME performance, we argue that proactiveness (Covin and Slevin 1989; Hite 2005) is a necessary antecedent for firms for network development in the context of trade shows and, therefore, propose:

Hypothesis 1: Proactiveness is positively related with ISMEs' development of networks through trade shows.

\subsection{Trade Show Networking and ISMEs' Performance}

Extant research has shown how SMEs can utilise their external networks to access foreign markets and gain customer knowledge essential for accelerated acquisition and expansion of foreign sales (Coviello 2006). However, only few studies have acknowledged the context of trade shows so far where this interorganisational networking generally occurs. Evers and Knight (2008) suggested that small internationalising firms utilise trade shows as network forums and nodes to gain access to their business and intermediary networks. Acting as temporary industry network spaces, trade shows have been conceptualised to be more than just a repository of information for the firms (Rosson and Seringhaus 1995).

Ryan et al.'s (2015) study on the digital animation sector found that industry trade shows were generally perceived to serve not only as a means of building vertical relations, but were often the principal forum for forging horizontal relationships with collaborative industry associates. In addition, social capital embeddedness developed in tight network space engendered a 'capital of trust' between network actors, thus permitting the industry members to enhance technical, intellectual, social and reputational capital (Ling-Yee 2006; Ryan et al. 2015, 2019).

Several studies have specifically shown that networks can be positively related to ISME performance, measured as international profit, sales, sales growth, and market share (Stoian et al. 2017). Ryan et al. (2019) suggest that local networks, internationally based networks, and the dyadic roles of local and international networks may affect ISMEs' performance (Musteen et al. 2010). The IB literature has generally found that networks are associated with ISME performance; however, contributions have been largely absent measuring the influence of networking at trade shows on ISME performance. Further, despite the widespread popularity and commercial significance of trade shows as global hubs of industry and commerce, we know little about the influence of trade show network activities on the performance of ISMEs. 
The majority of the literature in IB has investigated performance in the context of financial and operational dimensions (Gerschewski et al. 2015). This broad conceptualisation of performance is consistent with the seminal study by Venkatraman and Ramanujam (1986). The authors argued that when measuring performance of the firm, composite performance dimensions should be avoided, and they advocated rather a multi-faceted approach to measuring firm performance. In fact, Hult et al. (2008) found that most studies $(59.4 \%)$ used only one type of performance, while $32.3 \%$ used two performance types. Building on Venkataraman and Ramanujam's (1986) study, Gerschewski and Xiao (2015) found that operational performance measures were often considered as more important than financial indicators for ISMEs. For example, non-financial measures, such as market share and global reach, were frequently highly valued with the aim to grow from there through a combination of exporting, FDI, and licensing. This implies that operational performance with 'soft indicators' (e.g., 'global reach') can be instrumental in the internationalisation of SMEs, compared to the sole reliance on 'hard', financial measures. Following previous studies (e.g., Gerschewski and Xiao 2015), we examine and differentiate between the operational and financial dimensions of performance for ISMEs. Thus, the second hypothesis is:

Hypothesis $2 \mathrm{a} / \mathrm{b}$ : The development of networks through trade shows is positively related with the performance of ISMEs, as measured by a) operational, b) financial performance.

Companies generally perceive their trade show participation to mainly serve the operational goals encompassing two different types of activities: selling (e.g., achieve sales and revenues from trade shows) and non-selling (e.g., relationship and reputation; information gathering; market testing) (Shipley et al. 1993). Previous studies noted that non-selling objectives, such as meeting customers and better firm reputation, were often regarded as more important goals than selling (e.g., Shipley et al. 1993). Moreover, social rather than financial exchanges have been found to be critically important success factors at international trade shows, in particular, in the initial stages of relationships between two parties (e.g., Rice 1992). Gerschewski et al. (2015) found that ISMEs generally valued operational performance measures very highly. In addition, Evers and Knight (2008) found empirical evidence for ISMEs using trade shows more for 'softer', and non-financial rewards, rather than sales-related incentives. Thus, we propose:

Hypothesis 2c: The ISMEs' development of networks at trade shows has a stronger impact on the firms' operational performance than their financial performance.

\subsection{Performance of ISMEs and Industry Context}

The performance of ISMEs has been investigated from various perspectives, including performance drivers (e.g., Gerschewski et al. 2015), the role of networks (Evers and Knight 2008), and measurement of performance (e.g., Gerschewski and Xiao 2015). However, the role of the industry context for ISME performance has 
generally received limited focus in the literature, in particular, in terms of the relationships between ISMEs' network development and trade shows (Fernhaber et al. 2007).

We argue that industry exerts a moderating effect on the relationship between development of networks at trade shows and ISME performance. The structure and nature of industries often vary greatly, and, thus, provide the grounds why networks are more or less important for ISMEs' performance.

The importance and relevance of industry context have been noted in the literature (Andersson et al. 2014; Teagarden et al. 2018), calling for increased scientific rigor by contextualising and incorporating location and industry in academic research. Following these calls, we examine the moderating effect of industry on the relationship between network development and firm performance.

It is generally accepted that the service industry has a higher degree of industry internationalisation than manufacturing and other sectors (Ball et al. 2008; Erramilli 1992; Rammal and Rose 2014). Service firms worldwide often show a strong tendency to internationalise their business activities; global expansion and the launch of new services abroad are becoming an increasingly important issue for value creation and growth (Chandra et al. 2012). Accordingly, much research has focused on service internationalisation and, in particular, entrepreneurial activities and decisions that enable the exploitation of cross-border business opportunities through service internationalisation (Castaño et al. 2016; Javalgi and Martin 2007; Laudien and Daxböck 2017). The intangible nature of service products necessitates collaborative interactions between the service provider and the customer (e.g., Bitner 1990). Service industries are often characterised as 'high-contact', 'intangible', and 'one-to-one' (e.g., Erramilli 1992), which implies that personal interactions between frontline employees and customers are more integral compared to manufacturing industries. Thus, the need for customer-employee interactions is likely to be a relevant factor when sourcing services internationally. In addition, in the context of network development, price and quality, rather than after-sales customer service and 'one-to-one' customer interaction, are generally the primary drivers of company sales in manufacturing sectors, particularly in B-2-B industries. Trade shows provide the platform for developing personal interactions and relationships. Thus, we hypothesise:

Hypothesis 3a/b: The relationship between the development of networks through trade shows and a) operational, b) financial performance of ISMEs is moderated by industry, in that the effect is strengthened in the service industry.

\section{Methods}

\subsection{Sample and Procedures}

We collected data from ISMEs originating in Australia and New Zealand. Both countries are considered small and open economies (SMOPECs), where internationalisation is an important strategy for firm growth. To identify the target population, 
we collected the firms' details from Dun and Bradstreet by randomly selecting 2000 SMEs (1000 in each country) and inviting them to our web-based survey via email and two follow-up reminder emails. We received 310 questionnaires, which corresponds to a $15.5 \%$ response rate. After dropping questionnaires with incomplete data, we retained 229 responses in total. Our sample involves 151 New Zealand and 78 Australian ISMEs. The data collection occurred from April to July 2010. While the data may be perceived as relatively 'old', it should be noted that no major external events affecting the economy have happened in Australia and New Zealand since then, which may have impacted the performance of SMEs. In addition, recent follow-up interviews with $20 \mathrm{CEOs/senior} \mathrm{managers} \mathrm{of} \mathrm{the} \mathrm{sample} \mathrm{firms} \mathrm{in} 2019$ confirmed the validity of our findings.

Firm owners and/or CEOs (79\%) and sales managers (21\%) participated in our survey. In terms of industry, 78 (34\%) companies are operating in service industry such as professional, information, finance and accounting, 78 (34\%) companies are in manufacturing, and 73 (32\%) companies are operating in other industries, such as agriculture, forestry, fishing, mining, and construction. We tested non-response bias by categorising the data into early and late responses. Mann-Whitney U test showed that these two groups did not differ statistically, suggesting that non-response bias was no an issue.

\subsection{Measures}

We used measures from established sources, and applied 7-point Likert scales, unless otherwise stated.

We captured the independent variable, 'proactiveness', by three items from Hughes and Morgan (2007). The items of the scale asked respondents to evaluate how they described the international entrepreneurial orientation of their senior management and company. The Cronbach's alpha of the scale was 0.78 .

The mediating variable, 'development of networks through tradeshows', was measured using five items from Evers and Knight (2008), Shipley et al. (1993), and Kerin and Cron (1987). The items indicated how important the development of networks are for attending international trade shows, and the scale had a Cronbach's alpha of 0.73 .

We measured international performance considering both operational and financial performance using the scales from Gerschewski et al. (2015). This measure uses six items for measuring operational performance, such as market share in international markets, and four items from Venkatraman and Ramanujam (1986) and Vorhies et al. (1999) to measure financial performance, e.g., international profitability. The Cronbach's alpha of the two international performance scales were 0.93 and 0.91 , for operational and financial performance, respectively.

The marker variable was measured using three modified items based on Cavusgil and Zou (1994) and Madsen (1989). The items of the scale ask respondents to describe how potential their main foreign markets are, and the Cronbach's alpha of the scale was 0.73 . 
Following prior research (e.g., Wolff and Pett 2000), we controlled for company size (number of employees), firm sales (seven categories from less than USD 500,000 to more than USD 30 million), export sales ratio (0-100), and firm age (years).

\subsection{Preliminary Analysis}

We did confirmatory factor analysis (CFA) for all multi-item scales using the software programme $\mathrm{R}$ to validate the scales. We conceptualised 'proactiveness', 'development of networks through tradeshows', 'operational performance', and 'financial performance' as first-order factors, which can be freely correlated. CFA showed a good model fit: $\chi^{2}(128)=211.265$; CFI $=0.962$; RMSEA $=0.057$. Furthermore, all standardised loading estimates were higher than 0.50 , average variance extracted (AVE) and composite reliability of all the factors in the model greater than 0.50 and 0.70 respectively were indicators of convergent validity. We tested discriminant validity with the Fornell and Larcker (1981) method. Results showed that all AVEs were higher than the highest squared correlations, suggesting discriminant validity.

To test for common method bias (CMB), we conducted CFA marker analysis (Williams et al. 2010). We selected the construct of perception about how potential a main foreign market is as our marker variable. The theoretical rationale underpinning the selection is that most of previous theoretical models, which explain the variability of international performance of newly established firms (McDougall et al. 1994), only took the internationalisation of an industry into account. As a result, there is no clear conceptual linkage between the perception of how potential a foreign market is and international performance, network development through tradeshows, and proactive disposition of such firms. The satisfactory criteria for the marker variable are consistent with Williams et al. (2010) suggesting that a marker variable should be in the same format and expected to be theoretically unrelated with other variables. Thus, we are confident that any co-variation of the marker variable with our substantive variables could exist and may reflect some common method variance (CMV). As seen in

Table 1 Model fit indices and model comparisons for CFA models with marker variable

\begin{tabular}{|c|c|c|c|c|c|}
\hline Model & $\chi^{2}(\mathrm{df})$ & CFI & RMSEA (90\% CI) & LR of $\Delta \chi^{2}$ & Model comparison \\
\hline CFA with marker & $283.60(178)$ & 0.955 & $0.055(0.042,0.066)$ & & \\
\hline Baseline & $303.29(188)$ & 0.951 & $0.056(0.044,0.067)$ & & \\
\hline Method-C & 302.95 (187) & 0.950 & $0.056(0.044,0.067)$ & $\begin{array}{c}0.34, d f=1 \\
\rho=0.559\end{array}$ & vs. baseline \\
\hline Method-U & $250.61(170)$ & 0.966 & $0.049(0.035,0.061)$ & $\begin{array}{c}52.34, d f=17 \\
\rho=0.000\end{array}$ & vs. method-C \\
\hline Method-R & $251.39(176)$ & 0.968 & $0.047(0.033,0.059)$ & $\begin{array}{c}0.78, d f=6 \\
\rho=0.992\end{array}$ & vs. method-U \\
\hline
\end{tabular}

$L R$ likelihood ratior test, $C$ common, $U$ unconstrained, $R$ restricted 
Table 1, Method-C model does not statistically fit better than the Baseline model $\left(\Delta \chi^{2}(1)=0.34, \rho=0.559\right)$, indicating that CMV is not present when constraining method variance is equal. The Method-U model does statistically fit better than the Method-C $\left(\Delta \chi^{2}(17)=52.34, \rho=0.000\right)$, indicating the presence of CMV when method variance is not equally constrained. However, the Method-R is not statistically different than Method-U $\left(\Delta \chi^{2}(6)=0.78, \rho=0.992\right)$, indicating that CMV does not bias our results. Taken together, our post-hoc statistical results demonstrated that CMB was not a serious issue.

\section{Results}

We constructed moderated mediation model using lavaan in $\mathrm{R}$, to test our hypotheses. Table 2 summarises our descriptive results.

The $\mathrm{R}^{2}$ for operational and financial performance is $30.8 \%$ and $21.9 \%$ respectively, suggesting that our variables explain a substantial portion of our outcome variables. Next, we turn to testing our hypothesis (see Table 3). Proactiveness showed a significant positive relationship with network development through tradeshows $(b=0.31, S E=0.06, p<0.001)$, supporting hypothesis 1 . Hypothesis $2 \mathrm{a} / \mathrm{b}$ postulated a positive relationship between network development through tradeshows and operational and financial performance, respectively. Results demonstrated a positive association between network development through tradeshows and operational performance $(b=2.70, S E=0.78, p=0.001)$, but insignificant relationship with financial performance $(b=0.92, S E=0.91, p=0.315)$. Thus, hypothesis $2 \mathrm{a}$ finds support, whereas hypothesis $2 \mathrm{~b}$ is rejected. Hypothesis $2 \mathrm{c}$ predicted that the effect of the development of network is stronger on operational than on financial performance. We used the Wald statistics test to compare whether coefficients are significantly different. After constraining the equal direct effects of network development on each of the outcome variables, the Chi-square statistics is significantly different $\left(\chi^{2}(1)=4.942 ; p=0.033\right)$, implying that the effect of the development of networks at international trade shows is stronger on operational performance than financial performance. Therefore, hypothesis $2 \mathrm{c}$ is supported in our study.

Hypothesis $3 \mathrm{a}$ and hypothesis $3 \mathrm{~b}$ predicted that industry serves as a moderator in the relationships of network development through tradeshows with operational and financial performance, in that the effect is stronger in the service industry. The results showed no significant moderation effect in for operational performance $(b=-0.24, S E=1.58, p=0.851)$, whereas service industry significantly strengthened the association between network development and financial performance $(b=3.37, \mathrm{SE}=1.50, \mathrm{p}=0.025)$, relative to other industries. Thus, hypothesis $3 \mathrm{a}$ is rejected, while hypothesis $3 \mathrm{~b}$ is confirmed. We plotted the relationship between network development and financial performance by industries to illustrate the moderation effect (see Fig. 2).

We conducted a series of additional tests to further increase our understanding. First, we conducted the bootstrapping approach to estimate the confidence interval of mediation and moderated mediation effects. The results indicated the existence of mediation effect of network development through trade shows for operational 


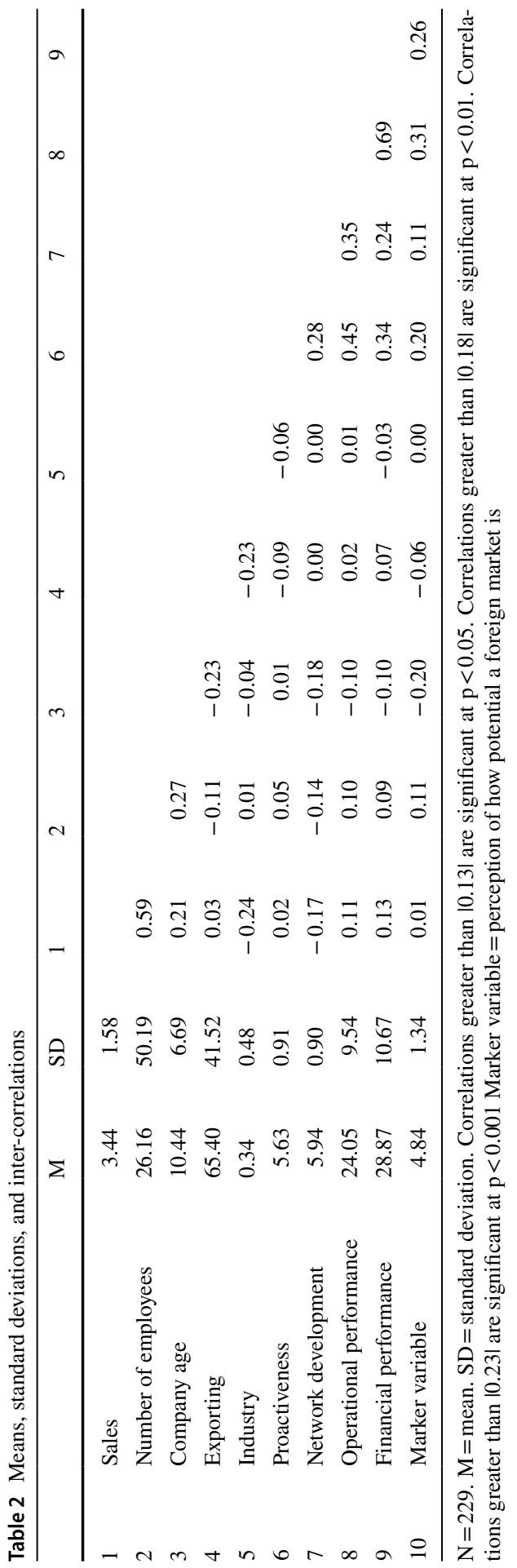




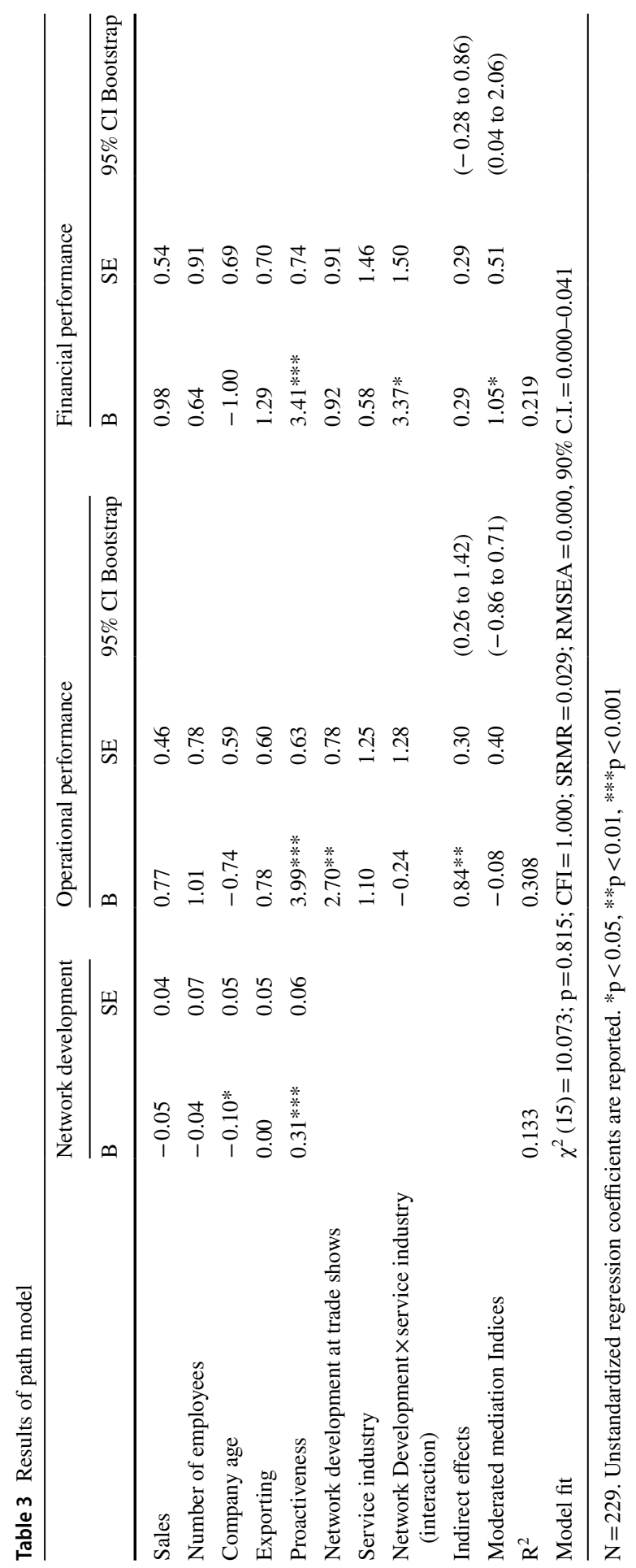




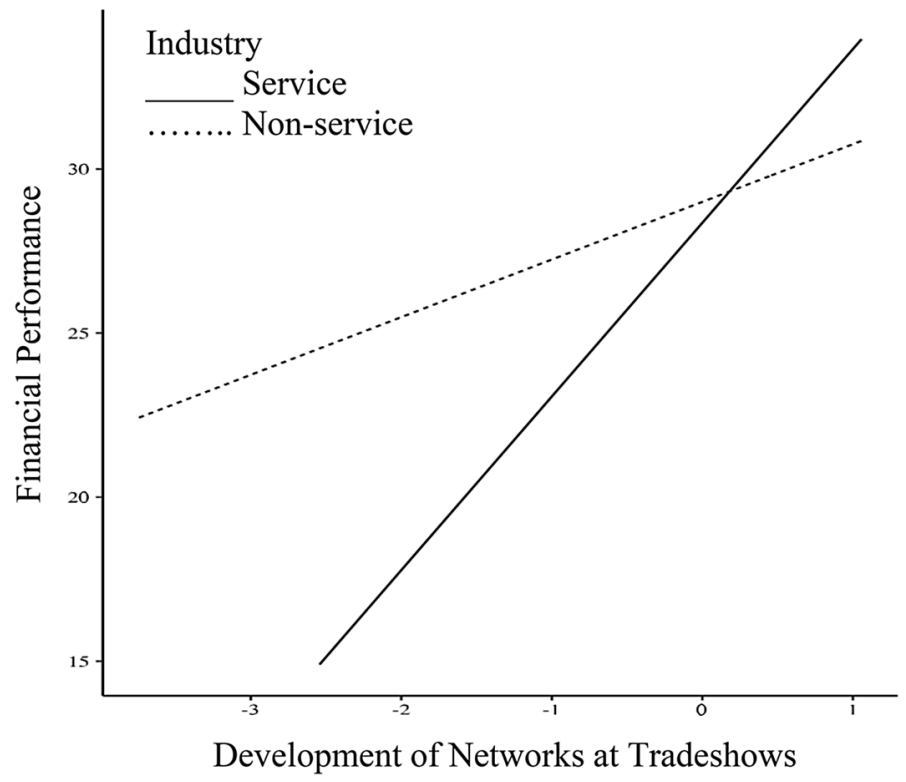

Fig. 2 Interaction plot

performance $(b=0.84, \mathrm{SE}=0.30,95 \% \mathrm{CI}=0.26-1.42)$, but not for financial performance $(b=0.29, \mathrm{SE}=0.29,95 \% \mathrm{CI}=-0.28-0.86)$. However, the estimates of moderated mediation effects indicated that the indirect effect of proactiveness on financial performance via network development through tradeshows became stronger in the service industry $(b=1.05, \mathrm{SE}=0.51,95 \% \mathrm{CI}=0.04-2.06)$. In terms of the mediation effect between proactiveness and operational performance, there was no difference between service and non-service sectors $(b=-0.08, S E=0.40, p=0.851,95 \%$ $\mathrm{CI}=-0.86-0.71)$. Given the established links between operational performance and financial performance, we further tested the direct effect between these two variables and the impact of network development through trade shows on financial performance through operational performance. Results indicated a positive association between operational and financial performance $(b=0.72, S E=0.06, p=0.000)$, and a significant indirect effect of network development at trade shows on financial performance that is carried via operational performance $(b=1.93, S E=0.59, p=0.001$, $95 \% \mathrm{CI}=0.78-3.08)$. The $\mathrm{R}^{2}$ for the financial performance in the model increased from 0.219 up to 0.513 , accounting for $51.3 \%$ variance of financial performance.

\section{Discussion}

We draw upon the network perspectives of firm internationalisation (Johanson and Vahlne 2009) to develop and test a model of how proactiveness influences network development through trade shows, which, in turn, influences performance, and the moderating role of industry. We surveyed Australian and New Zealand ISMEs to test 
our hypotheses. Our study supports the network perspective in explaining the performance of ISMEs, and further extends the impact of networks on ISMEs' operational and financial performance of trade shows. We discuss the key findings below.

First, we concur with the view that ISME proactiveness in network development activities can enable their acquisition of needed resources for their internationalisation process (Andersson et al. 2018; Evers 2011). Our results indicate that proactiveness enacted by ISMEs is positively related to network development at trade shows and an important antecedent as a means to enhance operational performance of ISMEs. ISMEs' knowledge and expectations of industry network actors within temporary global market spaces of trade shows enable them to proactively create and foster business relationships to gain global market reach through foreign market knowledge, customer referrals, market opportunity identification to short-circuiting product time to market. Our study suggests that the internationalisation process for SMEs involves learning via international networks (Sharma and Blomstermo 2003).

This is consistent with earlier studies (Evers 2011; Evers and Knight 2008) where small international firms have been found to be highly proactive in collecting market intelligence via various network channels at trade fairs. The perceived benefits accrued from networking at trade shows compelled ISMEs to proactively develop and mobilise networks as a necessary and strategic activity through which their firms' international market activities could be attained successfully.

Third, the positive association between development of networks at trade shows and operational performance of ISMEs suggests that the benefits of trade shows are often manifested in 'soft' and 'intangible' aspects for ISMEs, such as better firm reputation and 'global reach' of the firms. This study suggests that trade show forums or similar physical market spaces can be considered to co-exist with the network approach to understanding SME internationalisation. Our findings strengthen the view that trade shows, as temporary and industry spaces, are a valuable network infrastructure to establish networks for ISMEs' growth and superior performance.

Fourth, our study suggests that trade shows contribute to the development of a network infrastructure, confirming prior research (Evers and Knight 2008). This network infrastructure enabled ISMEs to connect to and leverage the on-site network business actors as a means to extend, penetrate, and integrate their networks for international growth. Moreover, trade show forums were perceived to serve as a means of organisational learning by building and nurturing relationships (Blythe 2002; Ling-Yee 2006; Measson and Campbell-Hunt 2015; Rosson and Seringhaus 1995; Ryan et al. 2019), to the extent that results in enhanced operational performance as our study concludes. This study extends research by advancing our knowledge on the positive impacts trade shows can accrue to ISMEs' operational performance (Crick 2009; Knight and Cavusgil 2004).

In contrast, the insignificant relationship between trade show activity and financial performance challenges some traditional insights considering sales activities as key incentives for trade show attendance (e.g., Shipley et al. 1993). In response to earlier calls in the literature (e.g., Tafesse and Skallerud 2017), this study further illuminates the importance in examining different types of performance to acquire deeper and more holistic insights into factors influencing ISME performance (Gerschewski et al. 2016). 
Finally, we hypothesised that the relationship between the development of networks through trade shows and performance of ISMEs is moderated by industry, in that the effect is strengthened in the service industry. The results support the hypothesis regarding financial performance, which indicates that network development is particularly important for boosting financial performance in the service industry, due to the high-contact and intangible nature of this industry (e.g., Erramilli 1992). Personal interactions are important to establish trust and finalise sales contracts. In contrast, the beneficial role of network development through trade shows for operational performance did not vary by industry. This suggests that all managers, regardless of industry context, perceive networking an important means to increase operational performance. Taken together, our findings suggest that networking at trade shows is universally considered important to achieve 'softer', operational performance goals (Evers and Knight, 2008), whereas it tends to be only important in the high-contact service industries to achieve financial performance goals.

\subsection{Theoretical Implications}

This study makes several theoretical contributions by providing valuable insights into the relevance of networks within the trade show forums for the performance of ISMEs. First, our study advances the network models of internationalisation positing that trade shows can represent important networking forums in which the phases of network internationalisation can occur (Johanson and Mattsson 1988). Proactiveness is found to be a necessary entrepreneurial orientation for firms to enact as a means to leverage and channel resources through networking at trade shows for firm performance. We have developed a conceptual model, including the role of tradeshows, networking and proactiveness, and we have empirically examined their impacts on ISMEs' performance.

Our study adds to the limited knowledge regarding the influence of networks on firm performance in the context of trade shows and ISMEs. Firstly, proactive trade show participation can enable the firm to gain insidership through access and establishment in a relevant market network in the trade show setting. Hence trade shows networks can be synonymous with the relevant market network to foreign markets thereby mitigating the firm's exposure to the liabilities of outsidership (Johanson and Vahlne 2009). This study suggests that trade shows enable early internationalising firms to become 'insiders' to their relevant foreign market networks.

Second, we conclude that trade show forums present a critical networking development space for ISME performance. This is a novel contribution, as there is relatively limited research on the forum or physical spaces where networking occurs and how networks link to performance in the context of trade fairs. Hence, our study is one of the first in the literature that investigates the quantitative influence of trade show networks on the performance of ISMEs operating across different industries. Our study provides a more comprehensive understanding of the function of network development through tradeshows on ISME performance, its antecedents, and the moderating role of industry. 
Third, this study emphasizes the significance of networking venues/forums and their roles in the overall process (Evers and Knight 2008). Networking nodes, such as trade shows, serve as loci to establish fundamental connections to enable early international market entry and penetration by extending the network of ISMEs in trade show forums and extend the firms' knowledge base needed for foreign market entry and growth. Given the resource constraints often experienced by ISMEs, the importance of trade shows as networking platforms becomes particularly pertinent.

This work extends previous knowledge in terms of the network perspective to examine the internationalisation process of ISMEs (e.g., Coviello 2006; Evers and Knight 2008). Despite growing interest in the topic, little is known about how ISMEs develop their networks in specific contexts and how that contributes to performance and how ISMEs gain access to relevant networks for internationalisation. This study addresses a research gap by offering empirical insights into the forum of the network in the internationalisation process - an area very much under-explored to date.

Fourth, we add to the IB literature by providing a more integrated view of performance, distinguishing between two performance dimensions (i.e., financial and operational). The literature has generally focused on examining only one type of performance (in particular, financial), rather than adopting a more integrated approach (see Gerschewski and Xiao 2015 for a review of ISMEs' performance measurement). This distinction is important as the effects of tradeshows can differ depending on the type of performance. While networking development through tradeshows has generally a more immediate effect on operational performance, our additional results suggest that it has an eventual indirect on financial performance: in other words, operational performance translates into financial performance in our study.

Fifth, we incorporate 'industry' as a critical contextual variable when examining the impact of networking, proactiveness, and trade shows on the performance implications for ISMEs. Previous related studies have often been sector-specific, and/or qualitative in nature (seafood by Evers and Knight 2008; digital animation by Ryan et al. 2015). We developed a cross-sector quantitative study, measuring the network developments at trade shows and their impact on the performance of ISMEs. Moreover, we examined the moderating effects of industry on the relationship between network development of ISMEs at trade shows and firm performance. Our study, thus, extends our knowledge by providing novel insights into the role of industry sector on the performance of ISMEs.

Finally, we contribute to the literature on early internationalisation in that we focus on the initial internationalisation of the sample firms (i.e., first 5 years of internationalisation). We also provide a contribution to the extension phase of internationalisation, as originally developed by Johanson and Mattsson (1988), and Johanson and Vahlne (2009), by advancing the role of tradeshows as networking mechanisms for facilitating firm insidership with the foreign market network, thereby reducing liabilities of outsidership for ISMEs. Given the resource constraints often experienced by ISMEs, the importance of trade shows as networking platforms becomes more pertinent. The initial internationalisation phase is often crucial for the eventual success of an ISMEs' international activities, in light of the key role for export readiness (Gerschewski et al. 2020). 


\subsection{Policy and Managerial Implications}

Our study provides key implications for policy-makers and managers. Policy-makers can build on these findings by encouraging exporters to attend trade fairs. In addition, as currently practiced by some state export promotion policies, policy-makers can provide financial support and advice for trade show attendance. The hosting of international trade fairs in their respective home countries could be an important step to strengthen the global exposure of firms operating in established and emergent sectors of strategic, economic importance. The pragmatic advice to ISME managers is relatively obvious: Try to be proactive and be open and flexible to participate in trade shows to develop networks.

Regarding managerial implications, our study provided support for the key roles of monitoring and measuring company performance in a differentiated manner by applying various types of performance, including financial and operational. Managers are well-advised to measure performance in a more holistic and integrated manner by incorporating the influence of the external environment (i.e., industry sector) on network development at trade shows and operational performance.

This study gives empirical evidence that the proactive development of networks at trade shows can have positive implications for firm performance. These results can motivate managers to devote attention to the importance of engaging proactiveness across staff at trade show to maximise the benefits for enhancing international performance. Providing trade show attending employees with proactive relationshipbuilding incentives could be critical to access market network structures through which they can exploit and mobilise available resources such as an extended knowledge base acquired through relationship- and network-specificity. Thus, senior managers are well-advised to leverage trade shows as 'spring boards' to successful, initial firm internationalisation.

\subsection{Limitations and Future Research}

The limitations of our study give rise to new directions for future research. ISMEs were based in Australia and New Zealand, which implies that the generalisability of the study's results to other country contexts is limited. More research on ISMEs from other country contexts, e.g., different cultures, could help to establish the generalisability of our findings and potentially add new insights.

This study relied on a cross-sectional survey collected from April-July 2010. We applied various ex-ante and statistical post-hoc strategies to counter common methods bias. Given the changing nature of networks (e.g., Hite 2005), future studies may conduct longitudinal studies to increase our understanding of the role of how ISMEs develop, grow, and maintain networks via trade shows and other means and how this may affect firm performance. The relative 'old age' of the data indicates that the validity of the data may have been compromised to some extent. However, recent interviews in 2019 with a selected group of the same respondents confirmed the validity of our findings. It should be noted that no major external changes affected 
these ISMEs since then. Future longitudinal research is encouraged to test whether and how external and internal changes influence the results of our findings.

Another promising line of future research could be the role of entry modes in network development at trade shows. For example, future research could examine the differences between exporters and firms that used alternative entry modes, such as licensing and equity modes or FDI (Cho and Lee 2018). Noting the important aspect of forums where networking occurs exposes an important component to be further researched in the network perspective of SME internationalisation.

Much work remains to be done on the operation and forums of networks. Future research could endeavour to explore other networking nodes, such as industry and network events. Such research could usefully explore beyond other industry sectors of this study.

As mentioned earlier, we hypothesise that trade shows are particularly pertinent to the early phase of internationalisation (e.g., Johanson and Mattson 1988), while the company is entering new foreign markets. The firms in our sample are SMEs, and, thus, generally lack financial and other resources. Therefore, the development of networks through tradeshows can help these SMEs reduce the resource constraints in their initial internationalisation endeavours and activities. We did not empirically test the differences between the impact of tradeshows on post-internationalisation and initial internationalisation, but this may form an interesting avenue for further research.

Finally, the investigation of any additional antecedents of network development at trade shows for ISMEs could be a promising future research area. For instance, the role of corporate culture and company ethics may be suitable starting points to further advance our knowledge in this increasingly relevant and intriguing research area.

Acknowledgements Open Access funding provided by Projekt DEAL.

Open Access This article is licensed under a Creative Commons Attribution 4.0 International License, which permits use, sharing, adaptation, distribution and reproduction in any medium or format, as long as you give appropriate credit to the original author(s) and the source, provide a link to the Creative Commons licence, and indicate if changes were made. The images or other third party material in this article are included in the article's Creative Commons licence, unless indicated otherwise in a credit line to the material. If material is not included in the article's Creative Commons licence and your intended use is not permitted by statutory regulation or exceeds the permitted use, you will need to obtain permission directly from the copyright holder. To view a copy of this licence, visit http://creativecommons.org/licen ses/by/4.0/.

\section{References}

Andersson, S., Evers, N., \& Gliga, G. (2018). Entrepreneurial marketing and born globals in China. Qualitative Market Research-An International Journal, 21(2), 202-231.

Andersson, S., Evers, N., \& Kuivalainen, O. (2014). International new ventures: Rapid internationalisation across different industry contexts. European Business Review, 26(5), 390-405.

Association of the German Trade Fair Industry. (2018). The trade fair market. https://www.auma.de/en/ facts-and-figures/the-trade-fair-market. Accessed 21 Dec 2018.

Axelsson, B., \& Easton, G. (1992). Industrial networks: A new view of reality. London: Routledge. 
Axinn, C. N. (1988). Export performance: Do managerial perceptions make a difference? International Marketing Review, 5(2), 61-71.

Ball, D., Lindsay, V. J., \& Rose, E. L. (2008). Rethinking the paradigm of service internationalisation: Less resource-intensive market entry modes for information-intensive soft services. Management International Review, 48(4), 413-431.

Bitner, M. J. (1990). Evaluating service encounters: The effects of physical surroundings and employee responses. Journal of Marketing, 54(2), 69-82.

Blomstermo, A., Eriksson, K., Lindstrand, A., \& Sharma, D. (2004). The perceived usefulness of network experiential knowledge in the internationalizing firm. Journal of International Management, 10(3), 355-373.

Brown, B., Mohan, M., \& Boyd, D. (2017). Top management attention to trade shows and firm performance: A relationship marketing perspective. Journal of Business Research, 81, 40-50.

Castaño, M., Méndez, M., \& Galindo, M. (2016). Innovation, internationalization and business-growth expectations among entrepreneurs in the services sector. Journal of Business Research, 69(5), 1690-1695.

Cavusgil, S. T., \& Zou, S. M. (1994). Marketing strategy-performance relationship: An investigation of the empirical link in export ventures. Journal of Marketing, 58(1), 1-21.

Chandler, G. N., \& Hanks, S. H. (1994). Market attractiveness, resource-based capabilities, venture strategies, and venture performance. Journal of Business Venturing, 9(4), 331-349.

Chandra, Y., Styles, C., \& Wilkinson, I. F. (2012). An opportunity-based view of rapid internationalization. Journal of International Marketing, 20(1), 74-102.

Cho, J., \& Lee, J. (2018). Internationalization and longevity of Korean SMEs: The moderating role of contingent factors. Asian Business \& Management, 17(2), 260-285.

Cho, J., \& Lee, J. (2020). Speed of FDI expansions and the survival of Korean SMEs: The moderating role of ownership structure. Asian Business \& Management, 19, 184-212.

Coviello, N. (2006). The network dynamics of international new ventures. Journal of International Business Studies, 37(5), 713-731.

Covin, J. G., \& Slevin, D. P. (1989). Strategic management of small firms in hostile and benign environments. Strategic Management Journal, 10(1), 75-87.

Crick, D., \& Spence, M. (2005). The internationalisation of 'high performing' UK high-tech SMEs: A study of planned and unplanned strategies. International Business Review, 14(2), 167-185.

Crick, D. (2009). The internationalisation of born global and international new venture SMEs. International Marketing Review, 26(4-5), 453-476.

Dean, D. L., Menguec, B., \& Myers, C. P. (2000). Revisiting firm characteristics, strategy, and export performance relationship: A survey of the literature and an investigation of New Zealand small manufacturing firms. Industrial Marketing Management, 29(5), 461-477.

Dess, G., \& Robinson, R. (1984). Measuring organizational performance in the absence of objective measures: The case of the privately-held firm and conglomerate business unit. Strategic Management Journal, 5(3), 265-273.

Erramilli, K., \& Rao, C. P. (1990). Choice of foreign market entry modes by service firms: Role of market knowledge. Management International Review, 30(2), 135-151.

Evers, N. (2011). Exploring Market orientation in new export ventures. International Journal of Entrepreneurship \& Innovation Management, 13(3-4), 357-374.

Evers, N., \& O'Gorman, C. (2011). Improvised internationalization in new ventures: The role of prior knowledge and networks. Entrepreneurship \& Regional Development, 23(7-8), 549-574.

Evers, N., Andersson, S., \& Hannibal, M. (2012). Stakeholders and marketing capabilities in international new ventures: Evidence from Ireland, Sweden and Denmark. Journal of International Marketing, 20(4), 46-71.

Evers, N., \& Knight, J. (2008). Role of international trade shows in small firm internationalization: A network perspective. International Marketing Review, 25(5), 544-562.

Evers, N., Gliga, G., \& Rialp-Criado, A. (2019). Strategic orientation pathways in international new ventures and born global firms-towards a research agenda. Journal of International Entrepreneurship., 17(3), 287-304.

Fernhaber, S. A., McDougall, P. P., \& Oviatt, B. M. (2007). Exploring the role of industry structure in new venture internationalization. Entrepreneurship Theory \& Practice, 31(4), 517-542.

Fornell, C., \& Larcker, D. F. (1981). Evaluating structural equation models with unobservable variables and measurement error. Journal of Marketing Research, 18(1), 39-50. 
Francis, J., \& Collins-Dodd, C. (2000). The impact of firms' export orientation on the export performance of high-tech small and medium-sized enterprises. Journal of International Marketing, 8(3), 84-103.

Gerschewski, S., Rose, E. L., \& Lindsay, V. J. (2015). Understanding the drivers of international performance for born global firms: An integrated perspective. Journal of World Business, 50(3), 558-575.

Gerschewski, S., Scott-Kennel, J., \& Rose, E. L. (2020). Ready to export? The role of export readiness for superior export performance of small and medium-sized enterprises. The World Economy, 43(5), 1253-1276.

Gerschewski, S., \& Xiao, S. S. (2015). Beyond financial indicators: An assessment of the measurement of performance for international new ventures. International Business Review, 24(4), 615-629.

Gerschewski, S., Lindsay, V. J., \& Rose, E. L. (2016). Advancing the entrepreneurial orientation construct: The role of passion and perseverance. Review of International Business and Strategy, 26(4), 446-471.

Gerschewski, S. (2017). Ready to export? Antecedents of export readiness for small and medium-sized enterprises. In Paper presented at the AIB UKI conference 2017, University of Reading, Henley Business School, UK.

Gerschewski, S., Lew, Y. K., Khan, Z., \& Park, B. I. (2018). Post-entry performance of international new ventures: The mediating role of learning orientation. International Small Business Journal, 36(7), 807-828.

Gupta, A. K., \& Govindarajan, V. (1984). Business unit strategy, managerial characteristics, and business unit effectiveness at strategy implementation. Academy of Management Journal, 27(1), 25-41.

Hansen, K. (1996). The dual motives of participants at international trade shows. International Marketing Review, 13(2), 39-53.

Harris, S., \& Wheeler, C. (2005). Entrepreneur's relationships for internationalization: Functions, origins and strategies. International Business Review, 14(2), 187-207.

Hite, J. M. (2005). Evolutionary processes and paths of relationally embedded network ties in emerging entpreneurial firms. Entrepreneurship Theory \& Practice, 29(1), 113-144.

Hughes, M., \& Morgan, R. E. (2007). Deconstructing the relationship between entrepreneurial orientation and business performance at the embryonic stage of firm growth. Industrial Marketing Management, 36(5), 651-661.

Hult, G. T. M., Ketchen, D. J., Jr., Griffith, D. A., Chabowski, B. R., Hamman, M. K., Dykes, B. J., et al. (2008). An assessment of the measurement of performance in international business research. Journal of International Business Studies, 39(6), 1064-1080.

Hymer, S. (1976). The international operations of national firms: A study of direct foreign investment. Cambridge: MIT Press.

Javalgi, R. G., \& Martin, C. L. (2007). Internationalization of services: Identifying the building blocks for future research. Journal of Services Marketing, 21(6), 391-397.

Jeong, S. W., Jin, B., Chung, J. E., \& Yang, H. (2017). Network evolution and cultivation patterns during the internationalization process: Case analyses from Korean SMEs. Asian Business \& Management, 16(6), 323-351.

Jin, B., \& Jung, S. (2016). Toward a deeper understanding of the roles of personal and business networks and market knowledge in SMEs' international performance. Journal of Small Business and Enterprise Development, 23(3), 812-830.

Johanson, J., \& Mattsson, L. G. (1988). Internationalization in industrial systems-a network approach. In N. Hood (Ed.), Strategies for global competition. London: Croom Helm.

Johanson, J., \& Mattsson, L. G. (1992). Network positions and strategic action-an analytical framework. In B. Axelsson \& G. Easton (Eds.), Industrial networks-a new view of reality (pp. 203-217). London: Routledge.

Johanson, J., \& Vahlne, J. E. (1990). The mechanism of internationalisation. International Marketing Review, 7(4), 11-23.

Johanson, J., \& Vahlne, J. E. (1992). Management of foreign market entry. Scandinavian International Business Review, 1(3), 9-27.

Johanson, J., \& Vahlne, J. E. (2003). Business relationship learning and commitment in the internationalisation process. Journal of International Entrepreneurship, 1(1), 83-101.

Johanson, J., \& Vahlne, J. E. (2009). The Uppsala internationalization process model revisited: From liability of foreignness to liability of outsidership. Journal of International Business Studies, 40(9), 1411-1431.

Jones, M. V., \& Coviello, N. E. (2005). Internationalisation: Conceptualising an entrepreneurial process of behaviour in time. Journal of International Business Studies, 36(3), 284-303. 
Jones, M. V., Coviello, N. E., \& Tang, Y. K. (2011). International entrepreneurship research (1989-2009): A domain ontology and thematic analysis. Journal of Business Venturing, 26(6), 632-659.

Karra, N., Phillips, N., \& Tracey, P. (2008). Building the born global firm: Developing entrepreneurial capabilities for international new venture success. Long Range Planning, 41(4), 440-458.

Kerin, R., \& Cron, W. (1987). Assessing trade show functions and performance: An exploratory study. Journal of Marketing, 51(1), 87-94.

Kirchgeorg, M., Springer, C., \& Kastner, E. (2010). Objectives for successfully participating in trade shows. Journal of Business \& Industrial Marketing, 25(1), 63-72.

Knight, G. A., \& Cavusgil, S. T. (2004). Innovation, organizational capabilities, and the born-global firm. Journal of International Business Studies, 35(2), 124-141.

Knight, G. A., \& Kim, D. (2009). International business competence and the contemporary firm. Journal of International Business Studies, 40(2), 255-273.

Kuivalainen, O., Sundqvist, S., \& Servais, P. (2007). Firms' degree of born-globalness, international entrepreneurial orientation and export performance. Journal of World Business, 42(3), 253-267.

Laudien, S. M., \& Daxböck, B. (2017). Enhancing the understanding of international new ventures: A service-oriented perspective. Management Research Review, 40(5), 494-516.

Ling-Yee, L. (2006). Relationship learning at trade shows: Its antecedents and consequences. Industrial Marketing Management, 35(2), 166-177.

Madsen, T. K. (1989). Successful export marketing management: Some empirical evidence. International Marketing Review, 6(4), 41-57.

Maskell, P., Bathelt, H., \& Malmberg, A. (2006). Building global knowledge pipelines: The role of temporary clusters. European Planning Studies, 14(8), 997-1013.

Mavrogiannis, M., Bourlakis, M. A., Dawson, P. J., \& Ness, M. R. (2008). Assessing performance in the Greek food and beverage industry-an integrated structural equation model approach. British Food Journal, 110(7), 638-654.

McDougall, P. P., Shane, S., \& Oviatt, B. M. (1994). Explaining the formation of international new ventures. Journal of Business Venturing, 9(6), 469-487.

McDougall, P. P., \& Oviatt, B. M. (2000). International entrepreneurship: The intersection of two research paths. Academy of Management Journal, 43(5), 902-906.

Measson, N., \& Campbell-Hunt, C. (2015). How SMEs use trade shows to enter global value chains. Journal of Small Business and Enterprise Development, 22(1), 99-126.

Musteen, M., Francis, J., \& Datta, D. K. (2010). The influence of international networks on internationalization speed and performance: A study of Czech SMEs. Journal of World Business, 45(3), 197-205.

O'Gorman, C., \& Evers, N. (2011). Network intermediaries in the internationalisation of new firms in peripheral regions. International Marketing Review, 28(4), 340-364.

Ojala, A., Evers, N., \& Rialp, A. (2018). Extending the international new venture phenomenon to digital platform providers: A longitudinal case study. Journal of World Business, 53(5), 725-739.

Oviatt, B. M., \& McDougall, P. P. (1994). Toward a theory of international new ventures. Journal of International Business Studies, 25(1), 45-64.

Parasuram, A. (1981). The relative importance of industrial promotional tools. Industrial Marketing Management, 10(4), 277-281.

Pinho, J. C., \& Prange, C. (2016). The effect of social networks and dynamic internationalization capabilities on international performance. Journal of World Business, 51(3), 391-394.

Rammal, H., \& Rose, E. L. (2014). New perspectives on the internationalization of service firms. International Marketing Review, 31(6), 550-556.

Rauch, A., Wiklund, J., Lumpkin, G. T., \& Frese, M. (2009). Entrepreneurial orientation and business performance: An assessment of past research and suggestions for the future. Entrepreneurship Theory \& Practice, 33(3), 761-787.

Rinallo, D., Bathelt, H., \& Golfetto, F. (2016). Economic geography and industrial marketing views on trade shows: Collective marketing and knowledge circulation. Industrial Marketing Management, 16, 93-103.

Rosenbusch, N., Rauch, A., \& Bausch, A. (2013). The mediating role of entrepreneurial orientation in the task-environment-performance relationship: A meta-analysis. Journal of Management, 39(3), 633-659.

Rosson, P., \& Seringhaus, F. H. R. (1995). Visitor and exhibitor interaction at industrial trade fairs. Journal of Business Research, 32(1), 81-90. 
Ryan, P., Evers, N., \& Smith, A. (2015). Born global networks: A study of the Irish digital animation sector. In J. Larimo \& N. Nummela (Eds.), Handbook of international alliances and networks (pp. 297-319). London: Routledge.

Ryan, P., Evers, N., Smith, A., \& Andersson, S. (2019). Local horizontal network membership for accelerated global market reach. International Marketing Review, 35(6), 936-957.

Sapienza, H. J., Smith, K. G., \& Gannon, M. J. (1988). Using subjective evaluations of organizational performance in small business research. American Journal of Small Business, 12(3), 45-54.

Sharma, D. D., \& Blomstermo, A. (2003). The internationalisation process of born globals: A network view. International Business Review, 12(6), 739-753.

Shipley, D., Egan, C., \& Wong, K. S. (1993). Dimensions of trade show exhibiting management. Journal of Marketing Management, 9(1), 55-63.

Stoian, M., Rialp, J., \& Dimitratos, P. (2017). SME networks and international performance: Unveiling the significance of foreign market entry mode. Journal of Small Business Management, 55(1), $128-148$.

Tafesse, W., \& Skallerud, K. (2015). Towards an exchange view of trade fairs. Journal of Business \& Industrial Marketing, 30(7), 795-804.

Tafesse, W., \& Skallerud, K. (2017). A systematic review of the trade show marketing literature: 19802014. Industrial Marketing Management, 63(3), 18-30.

Tan, A., Brewer, P., \& Liesch, P. W. (2007). Before the first export decision: Internationalisation readiness in the pre-export phase. International Business Review, 16(3), 294-309.

Tan, A., Brewer, P., \& Liesch, P. W. (2018). Rigidity in SME export commencement decisions. International Business Review, 27(1), 46-55.

Teagarden, M. B., Von Glinow, M. A., \& Mellahi, K. (2018). Contextualizing international business research: Enhancing rigor and relevance. Journal of World Business, 53(3), 303-306.

Teece, D. J. (2000). Strategies for managing knowledge assets: The role of firm structure and industrial context. Long Range Planning, 33(1), 35-54.

U.S. Small Business Administration. (2018). Market research and competitive analysis. https://www. sba.gov/business-guide/plan-your-business/market-research-competitive-analysis. Accessed 10 Oct 2018.

Venkatraman, N., \& Ramanujam, V. (1986). Measurement of business performance in strategy research: A comparison of approaches. Academy of Management Review, 11(4), 801-814.

Vorhies, D. W., Harker, M., \& Rao, C. P. (1999). The capabilities and performance advantages of marketdriven firms. European Journal of Marketing, 33(11-12), 1171-1202.

Wilkinson, T., \& Brouthers, L. E. (2006). Trade promotion and SME export performance. International Business Review, 15(3), 233-252.

Wilkinson, T. J., \& Brouthers, L. E. (2000). An evaluation of state sponsored promotion programs. Journal of Business Research, 47(3), 229-236.

Williams, L. J., Hartman, N., \& Cavazotte, F. (2010). Method variance and marker variable-a review and comprehensive CFA marker technique. Organizational Research Methods, 13(3), 477-514.

Wolff, J. A., \& Pett, T. L. (2000). Internationalization of small firms: An examination of export competitive patterns, firm size, and export performance. Journal of Small Business Management, 38(2), 34-47.

Zain, M., \& Ng, S. I. (2006). The impacts of network relationships on SMEs' internationalisation process. Thunderbird International Business Review, 48(2), 183-205.

Publisher's Note Springer Nature remains neutral with regard to jurisdictional claims in published maps and institutional affiliations. 